\title{
Characterising Particulate Organic Nitrogen at A Savannah-Grassland Region in South Africa
}

\author{
Wanda Booyens ${ }^{1}$, Pieter G. Van Zyl ${ }^{1, *} \mathbb{0}$, Johan P. Beukes ${ }^{1}$, Jose Ruiz-Jimenez ${ }^{2}$, \\ Matias Kopperi ${ }^{2}$, Marja-Liisa Riekkola ${ }^{2}(0)$, Ville Vakkari ${ }^{1,3}$, Miroslav Josipovic ${ }^{1}$, \\ Markku Kulmala ${ }^{4}$ and Lauri Laakso ${ }^{1,3}$ \\ 1 Unit for Environmental Science and Management, North-West University, Private Bag X6001, \\ Potchefstroom 2520, South Africa \\ 2 Department of Chemistry, University of Helsinki, PO Box 55, 00014 Helsinki, Finland \\ 3 Finnish Meteorological Institute, PO Box 503, 00101 Helsinki, Finland \\ 4 Department of Physical Sciences, University of Helsinki, P.O. Box 64, 00014 Helsinki, Finland \\ * Correspondence: pieter.vanzyl@nwu.ac.za; Tel.: +27-18-299-2353
}

Received: 29 July 2019; Accepted: 20 August 2019; Published: 26 August 2019

check for updates

\begin{abstract}
Although atmospheric organic N compounds are considered to be important, especially in new particle formation and their contribution to brown carbon, these species are not that well understood. This can be partially attributed to their chemical complexity. Therefore, the aim of this study was to assess the characteristics of organic $\mathrm{N}$ compounds utilising comprehensive two-dimensional gas chromatography coupled with a time-of-flight mass spectrometer (GCxGC-TOFMS) in aerosol samples that were collected at a savanna-grassland background region and to determine the possible sources. 135 atmospheric organic $\mathrm{N}$ compounds were tentatively characterised and semi-quantified, which included amines, nitriles, amides, urea, pyridine derivatives, amino acids, nitro-and nitroso compounds, imines, cyanates and isocyanates, and azo compounds. Amines contributed to $51 \%$ of the semi-quantified concentrations, while nitriles, pyridine derivatives, and amides comprised $20 \%, 11 \%$, and $8 \%$, respectively, of the semi-quantified concentrations. Amines, nitriles, amides, and pyridine derivatives concentrations were higher during the dry season, which were attributed to meteorology and open biomass burning. Anthropogenic sources impacting air masses measured at Welgegund, as well as regional agricultural activities, were considered as the major sources of amines, while the regional influence of household combustion was most likely the main source of nitriles, amides, and pyridine derivatives. The other organic $\mathrm{N}$ species were most likely related to the influence of local and regional agricultural activities.
\end{abstract}

Keywords: atmospheric aerosols; organic aerosols; amines; agricultural; GCxGC-TOFMS; Welgegund

\section{Introduction}

Nitrogen $(\mathrm{N})$ - one of the most important elements in the environment-is converted into different chemical forms in ecosystems through the biogeochemical cycle of $\mathrm{N}$, which includes biological (e.g., microbial activity) and physical (e.g., reaction with $\mathrm{O}$ ) processes [1]. Typical $\mathrm{N}$ species in the environment include nitrogen oxide $(\mathrm{NO})$, nitrogen dioxide $\left(\mathrm{NO}_{2}\right)$, ammonia/ammonium $\left(\mathrm{NH}_{3} / \mathrm{NH}_{4}{ }^{+}\right)$, nitrate $\left(\mathrm{NO}_{3}{ }^{-}\right)$, nitrous oxide $\left(\mathrm{N}_{2} \mathrm{O}\right)$, and organic nitrogen. The characteristics and occurrences of most of these $\mathrm{N}$ species in the atmosphere have been extensively studied. However, although atmospheric organic $\mathrm{N}$ compounds are considered to be important to the global atmospheric $\mathrm{N}$ budget, especially in the particulate and aqueous phases [2,3], these species are not that well understood [4] and not routinely assessed [5]. Atmospheric particulate organic N compounds are primarily emitted from natural and anthropogenic sources [4] (and references therein) or they can be formed in the atmosphere 
as secondary pollutants [6]. Jickells et al. [3] indicated that the four sources are considered to be important for particulate organic N, i.e., soil dust (e.g., [7]), biomass burning (e.g., [8]), marine emissions (e.g., [9]), as well as anthropogenic and agricultural sources [7,10]. In addition, vegetation (biogenic emissions) can also be an important source of organic N [11]. Organic $\mathrm{N}$ are considered to be important to the long-range transport of $\mathrm{N}[12,13]$ due to their removal process being less effective as compared to that of $\mathrm{NO}_{3}{ }^{-}$and $\mathrm{NH}_{4}{ }^{+}[5]$.

The impacts of organic $\mathrm{N}$ on biogeochemistry, ecosystems, and human health are well documented [5,14-16]. Numerous studies have been conducted that indicate the importance of organic $\mathrm{N}$ to new particle formation and particle growth, especially studies that are related to the role of amines in secondary particulate formation $[11,17,18]$. Almeida et al. [18] indicated that the influence of amines and sulphur dioxide on new particle formation should be considered in regions within proximity of sources of amines. In addition, organic $\mathrm{N}$ compounds, e.g., amines and amino acids, are important precursor species in the formation of atmospheric brown carbon $[19,20]$. The importance of atmospheric brown carbon has been indicated in various recent studies [21-23], due to its influence on light absorption and the subsequent impacts on climate change. A recent modelling study indicated that 20 to $70 \%$ of black carbon forcing can be attributed to brown carbon forcing [24].

An important factor to particulate organic organic $\mathrm{N}$ species being understudied relates to their chemical complexity [4]. Compounds that were previously characterised in individual studies include amines, amino acids, urea, nitrophenols, alkyl amides, $N$-heterocyclic alkaloids, and organic nitrates [3]. Bulk analysis, which includes filter sampling or near real-time sampling, e.g., aerosol mass spectrometry (AMS) estimates, determine the total concentrations of organic N. Although bulk analysis provides information regarding the general chemical composition, oxidation state, and reactivity of these species [4], it provides limited information on the actual character of individual organic $\mathrm{N}$ compounds, sources of these species, and their impacts on the environment. Therefore, analytical techniques with more precise speciation are required in order to more specifically characterise organic $\mathrm{N}$ species, which will assist in determining the sources of these species and establishing their impacts on the environment. One such method entails the characterisation of organic atmospheric aerosols that were collected on filters with comprehensive two-dimensional gas chromatography coupled with a time-of-flight mass spectrometer (GCxGC-TOFMS) [25-27], which is a powerful instrument for the chemical characterisation of organic compounds in complex matrices.

Limited studies have been conducted utilising GCxGC analysis to determine organic $\mathrm{N}$ in aerosols [28]. Booyens et al. [29] recently utilised GCxGC-TOFMS for the first time in South Africa to tentatively identify and semi-quantify the organic compounds in ambient aerosols collected on filters for three different size fractions ( $\mathrm{PM}_{1}, \mathrm{PM}_{2.5-1}$ and $\left.\mathrm{PM}_{10-2.5}\right)$ at a regional background site, i.e., Welgegund situated in the grassland-savannah region. These aerosol samples were also additionally assessed by Booyens et al. [30] with regard to the seasonal variability of polar organic aerosols that are associated with meteorological and source region influences. In view of the importance of atmospheric organic $\mathrm{N}$, and when considering that these species are currently understudied as indicated above, the aim of this study was to further explore this ambient aerosol dataset collected at Welgegund in order to assess the characteristics of organic $\mathrm{N}$ compounds and to determine the possible sources. The dataset was assessed in view of the possible temporal variability of different $\mathrm{N}$-containing organic functional groups, while a few specific organic $\mathrm{N}$ compounds are also highlighted. In addition, according to the knowledge of the authors, this is the first study in which a comprehensive number of particulate organic $\mathrm{N}$ compounds are tentatively characterised and semi-quantified in southern Africa. More detailed chemical characterisation of different organic $\mathrm{N}$ functional groups will improve our understanding of the influence of particulate matter on general air quality, as well as their impacts on climate (e.g., their role in new particle formation) in this region. 


\section{Measurement Location and Methods}

\subsection{Site Description}

The Welgegund monitoring station (latitude $26^{\circ} 34^{\prime} 10^{\prime \prime} \mathrm{S}$, longitude $26^{\circ} 56^{\prime} 21^{\prime \prime} \mathrm{E}, 1480 \mathrm{~m}$ AMSL) is a comprehensively equipped atmospheric measurement station that is located within the South African Highveld approximately $100 \mathrm{~km}$ west of Johannesburg on a commercial farm. The site is a regionally representative background site with no direct impacts from large pollution sources in close proximity. However, it is impacted by plumes passing over the major anthropogenic source regions in the interior of South Africa. A number of papers on atmospheric measurements that were conducted at Welgegund have been published, wherein detailed descriptions of measurements conducted [31-33], geographical and bioregion location [29,34], and the major source regions affecting Welgegund [35] have been presented.

\subsection{Sampling and Analysis}

The methodology that was developed by Booyens et al. [29] and Ruiz-Jimenez et al. [36] was applied for the determination of organic $\mathrm{N}$ compounds in 52 ambient atmospheric aerosol samples that were collected at Welgegund. Briefly, 24-h ambient aerosol samples in the $\mathrm{PM}_{1}, \mathrm{PM}_{2.5-1}$, and $\mathrm{PM}_{10-2.5}$ size ranges were collected on quartz filters once a week from 12 April 2011 until 4 April 2012 with a Dekati $\mathrm{PM}_{10}$ cascade impactor at a flow rate of $30 \mathrm{~L} / \mathrm{min}$. The filters were extracted utilising dynamic ultrasonic-assisted extraction after which three separate aliquots from each sample were further pre-concentrated prior to analysis with a LECO Pegasus 4D two-dimensional gas chromatograph coupled to a time-of flight mass spectrometer (GCxGC-TOFMS). The first aliquot was directly analysed, while the other two aliquots were derivatised in order to transform non-volatile compounds into volatile compounds. The characterisation and semi-quantification of organic compounds are discussed in detail in Booyens et al. [29]. The organic $\mathrm{N}$ compounds characterised are considered to be tentatively identified species due to the less restrictive positive characterisation parameters that are applied (mass spectral matching in the NIST library, automated comparison of experimental and theoretical retention indices and identification with the Golm metabolome database) [29]. The concentrations of the organic $\mathrm{N}$ compounds tentatively characterised were expressed as relative response factors (RRF) in relation to the internal standard (1-1'binaphthyl), which were calculated by: RRF $=\left(A_{c i} / A_{\mathrm{IS}}\right)\left(A_{c i}=\right.$ peak area of the compound; $A_{\mathrm{IS}}=$ peak area of the internal standard). RRFs were normalised per volume of air sampled and presented as the sum of the normalised RRF of different organic $(\mathrm{N})$ compounds ( $\sum \mathrm{NRRF}$ ). The 1-1'binaphthyl internal standard was also used in two studies by Ruiz-Jimenez et al. [36,37] to semi-quantify the $\mathrm{N}$ organic compounds.

\section{Results and Discussion}

In Figure 1a, the total number of organic $\mathrm{N}$ species that were tentatively identified for all the samples collected with their corresponding $\sum$ NRRFs in the three size ranges are contextualised in relation to the other functional group categories. In total, 135 organic $\mathrm{N}$ compounds could be tentatively characterised in all three size ranges, contributing $13 \%$ of the total number of organic compounds and $12 \%$ of the total $\sum$ NRRFs for all of the organic species tentatively identified. In Figure $1 \mathrm{~b}$, the total numbers of each of the organic $\mathrm{N}$ functional groups, i.e., amines, amides, amino acids, azo-compounds, imines, cyanates, isocyanates, nitriles, nitro, nitroso, pyridine derivatives, and urea, tentatively identified, are presented with their respective $\sum$ NRRFs. As indicated by Booyens et al. [29], all of the pyridine compounds identified in samples that were derivatised with pyridine prior to analysis were excluded from dataset. The largest number of organic $\mathrm{N}$ species tentatively identified in all size fractions was amines ( $29 \%$ of total number of organic $N$ species), which were also the most abundant species, as indicated by their respective combined $\sum$ NRRFs ( $51 \%$ of total $\sum$ NRRFs of all organic N species). According to the $\sum$ NRRFs, nitriles were the second most abundant species $(20 \%$ of total $\sum N R R F$ s of all organic $\mathrm{N}$ species), while the pyridine derivatives and amides also have relatively 
higher $\sum$ NRRFs (11 and $8 \%$ of total $\sum N R R F$ s of all organic $\mathrm{N}$ species, respectively). In addition, a relatively large number of pyridine derivatives ( $20 \%$ of total number of organic $\mathrm{N}$ species) species was tentatively characterised. The semi-quantified concentrations of all the other organic $\mathrm{N}$ species were very low. Each of these organic $\mathrm{N}$ functional groups that were tentatively characterised will be discussed in detail in subsequent sections.
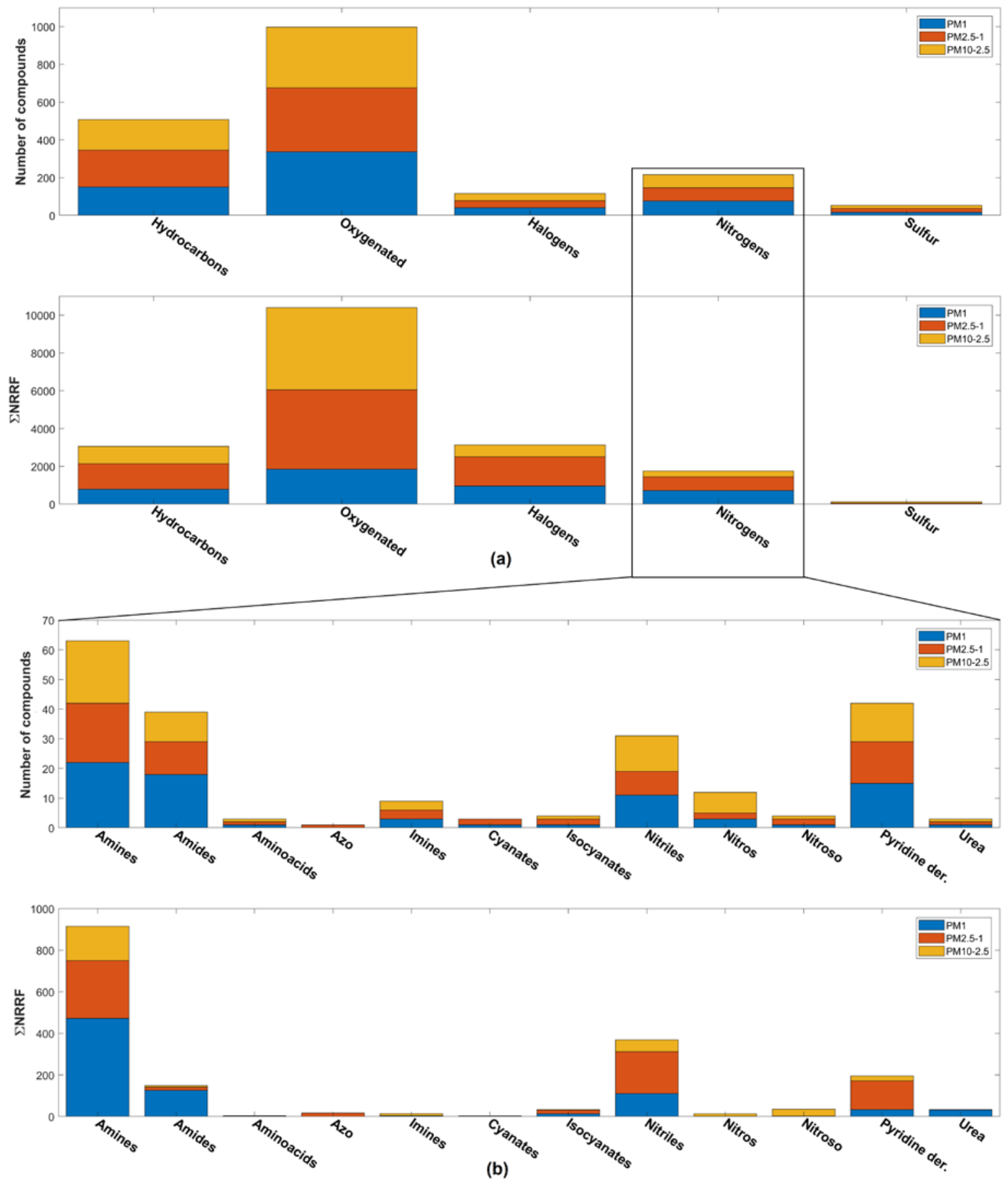

Figure 1. $(\mathbf{a}, \mathbf{b})$ Contextualisation of nitrogen-containing functional groups in relation to the total number of compounds tentatively identified with their associated normalised relative response factors $(\Sigma$ NRRFs) of different organic $(\mathrm{N})$ compounds for each of the functional group categories in the three particle size ranges (adapted from Figures 4 and 8 in Booyens et al. [29]). 
The organic N compounds that were characterised in this study utilising GCxGC-TOFMS can be contextualised with other studies, in which $\mathrm{N}$-containing organic compounds were identified in atmospheric aerosols with two-dimensional gas chromatography. In a study that was conducted by Özel et al. [15], which characterised and semi-quantified organic $\mathrm{N}$ compounds in $\mathrm{PM}_{2.5}$ samples collected in an urban area in Birmingham, England while using DTD (direct thermal desorption)-GCxGC-TOFMS, 114 organic $\mathrm{N}$ compounds were identified. Of the total number of organic samples detected in each sample, 2 to $7 \%$ of the species were organic N. Özel et al. [15] indicated that $\sim 33 \%$ of organic $\mathrm{N}$ were nitriles, $14 \%$ were amides, $7 \%$ were amines, and $6 \%$ were nitro compounds. Ochiai et al. [38] tentatively characterised 15 organic N species with TD-GCxGC-NPD (-nitrogen phosphorous detector)/qMS (quadropole MS) for aerosol samples that were collected in the $0.058 \mu \mathrm{m}$ size range at a roadside crossing in Kawasaki, Japan, which included five nitriles, four alkaloids, two quinolines, one amide, one amine, one pyridine, and one azole. In addition, Schnelle-Kreis et al. [39] utilised DTD-GCxGC-TOFMS to characterise and semi-quantify a series of nitriles among other organic compounds for $\mathrm{PM}_{2.5}$ samples that were collected in Augsburg, Germany. The variances in contributions of respective organic $\mathrm{N}$ functional groups to the total number of $\mathrm{N}$-containing compounds detected can be attributed to the different types of environments in which atmospheric aerosol samples were collected, i.e., mostly urban sites, while Welgegund is a regional background site.

\subsection{Amines}

Although atmospheric amine species have been more extensively studied when compared to other atmospheric organic $\mathrm{N}$ species, as indicated by a comprehensive review [11], these species are still considered to be understudied, especially studies that are related to their atmospheric chemistry. The amine functional group is considered to be the organic derivative of inorganic $\mathrm{NH}_{3}$. Similar to the basic character that dominates the chemistry of $\mathrm{NH}_{3}$, amines are also basic compounds [40]. Therefore, atmospheric amine species are also important in neutralising acidic species in the atmosphere [11]. In addition, as previously mentioned, atmospheric amines play an important role in secondary organic aerosol (SOA) formation [40]. Almeida et al. [18], for example, recently indicated that dimethyl amine increased the particle growth formation rates by more than 1000-fold when compared to ammonia. Therefore, when considering that recent studies have indicated (a) an increase in the acidity of rain water samples collected during the last decade over the South African Highveld [41], as well as (b) record-high frequencies of nucleation events occurring in this region [42,43], these species are important.

Anthropogenic sources dominate the emissions of amines, with the main sources including livestock and animal husbandry, industry and combustion, composting operations, automobiles, and other human activities (e.g., sewage, cooking and charbroiling, corrosion inhibitors, tobacco smoke, indoor textile, pesticides) [11]. The major natural sources identified include the ocean, soil, biomass burning, and vegetation. As mentioned above, Welgegund is influenced by the major anthropogenic source regions in the interior of South Africa, with many of the anthropogenic activities listed here occurring in these source regions. Furthermore, since Welgegund is located on a commercial farm, animal husbandry/livestock (cattle and sheep) could also be a local source of the amine species measured.

In total, 63 amines were tentatively characterised in all three size fractions. As indicated above, the largest number of organic $\mathrm{N}$ species identified were amine compounds, for which their respective combined $\sum N R R F s$ also indicated significantly higher semi-quantified concentrations as compared to the other organic $\mathrm{N}$ species that were characterised in this study. Booyens et al. [29] indicated that the $\sum N R R F$ s of amines in the $\mathrm{PM}_{1}$ size fraction are especially significant, since it contributes approximately $10 \%$ to the total $\sum$ NRRFs of all the organic compounds measured in the $\mathrm{PM}_{1}$ size fraction. One specific amine compound, i.e., 2-methyl-2-propanamine, contributed $25 \%$ of the total $\sum$ NRRF of amines in the $\mathrm{PM}_{1}$ size fraction, which occurred in the $\mathrm{PM}_{1}$ size fraction of many of the samples collected.

In Figure 2, the total number of amines tentatively identified and their corresponding $\sum N R R F$ s in the three size ranges for each sample collected during the entire sampling period are presented. No distinct seasonal pattern for the total number of amines and their $\sum$ NRRFs is observed in Figure 2. 
However, the temporal variations of amines do correspond with the three different periods that were indicated by Booyens et al. [30] for all polar organic aerosols and all $\mathrm{N}$-containing organic compounds, i.e., the period between 2 August 2011 and 04 October 2011 (late winter to early spring) with a significantly lower number of amines and corresponding $\sum$ NRRFs, as well as a relatively higher number of amines and associated $\sum$ NRRFs for the sampling period 12 April 2011 to 12 July 2011 (mid-autumn to mid-winter) when compared to the sampling period between 11 October 2011 and 4 April 2012 (late spring to mid-autumn). In Appendix A, the average $\sum$ NRRFs of amines, nitriles, amides, and pyridine derivatives measured during the three different periods that were indicated by Booyens et al. [30] are presented, which also signifies the semi-quantified amine concentrations corresponding to these three periods. These temporal variations were attributed to source region influence, meteorological parameters, and the influence of open biomass burning [30]. The period with a significantly lower total number of amines and $\sum N R R F$ s correspond with the peak open biomass burning season in this region. The significantly lower concentrations of polar organic compounds were ascribed to Welgegund being impacted by fresher biomass burning plumes mainly containing primary emitted VOCs and non-polar hydrocarbon aerosols [30]. Furthermore, meteorological parameters indicated that the period with a relatively higher number of polar organic compounds and corresponding $\sum N R R F s$ was attributed to a decrease in wet removal during the dry season, which can be especially significant for amine compounds that are generally considered to be water-soluble. In addition, the occurrence of more pronounced inversion layers could also contribute to the build-up of local amine emissions from sources like animal husbandry.

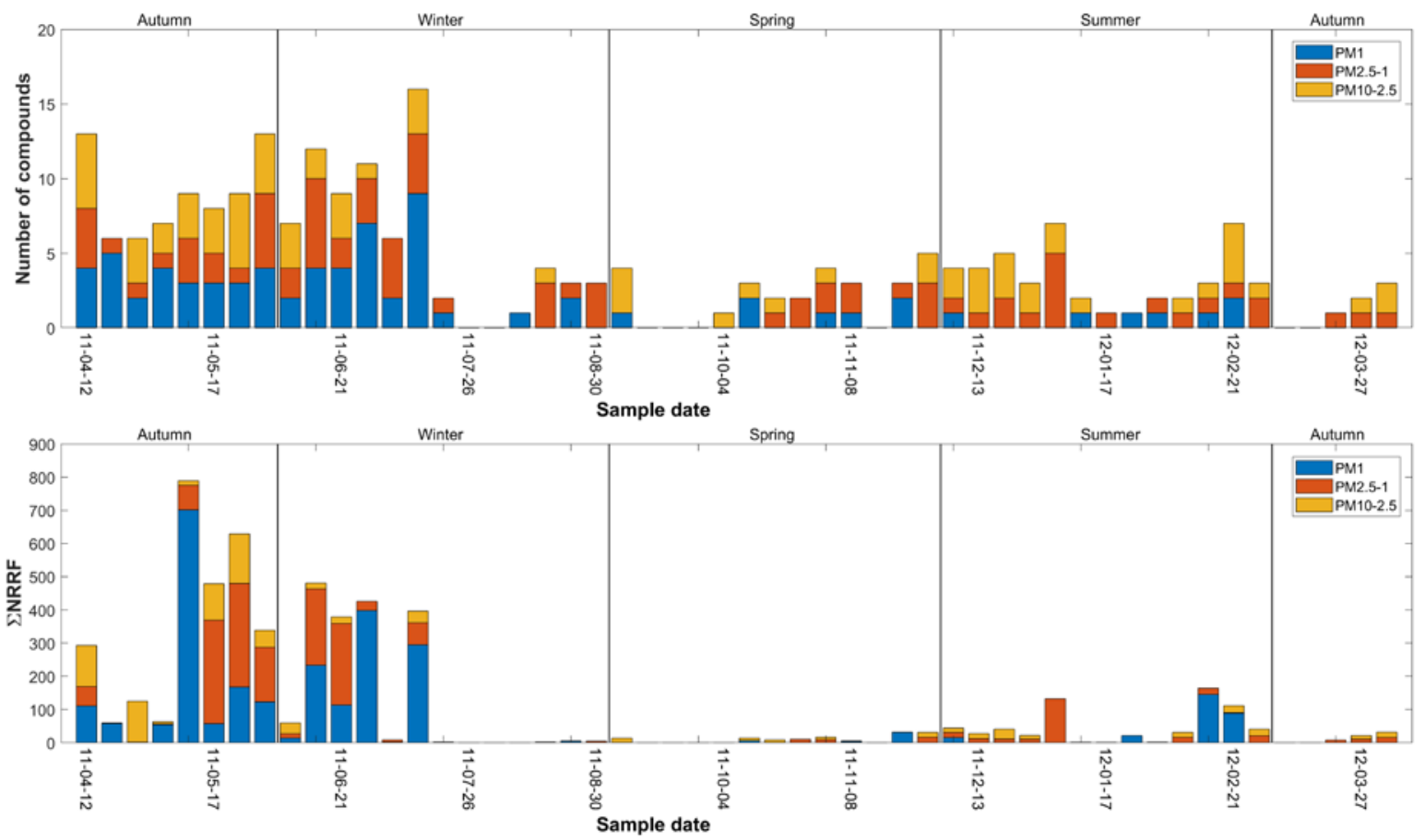

Figure 2. Total number of amines identified and their corresponding semi-quantified concentrations $(\Sigma N R R F s)$ in the three particle size fractions for each sample collected.

\subsection{Nitriles, Amides and Urea}

Biomass burning and cooking are considered to be the main sources of organic nitriles and amides in the atmosphere [4,44]. Additionally, amides can also be formed from atmospheric accretion reactions (reactions of organic compounds with each other and/or other atmospheric species to form products that are higher in molecular weight and lower in volatility) of organic acids with amines and ammonia [45] and the degradation processes of amines [46]. As mentioned above, nitriles were the second most abundant species (combined total of $\sum$ NRRFs in all three size fractions), while 
amides were the fourth most abundant species. In total, 31 nitrile and 39 amide compounds were tentatively characterised in all three size fractions. Although more amide species were characterised when compared to nitrile compounds, the $\sum$ NRRFs of amides were significantly lower. According to the semi-quantified concentrations, amides predominantly occurred in the $\mathrm{PM}_{1}$ size fraction, which is indicative of secondary formation of particulate atmospheric amides being an important source of these species. Nitriles had relatively higher concentrations in the $\mathrm{PM}_{2.5-1}$ size fraction.

In Figures 3 and 4, the total number of nitriles and amides tentatively identified in the three size ranges are presented, respectively, with their corresponding semi-quantified concentrations. Similar to amines, the temporal variations of nitriles and amides also correspond with the three periods that were observed for all polar and $\mathrm{N}$-containing organic aerosols (Appendix A) [30]. However, the total number of amides and nitriles with their corresponding $\sum N R R F s$ were significantly lower for the period between 11 October 2011 and 4 April 2012 (wet season) than the period from 12 April 2011 to 12 July 2011 (dryer period), with no nitriles and amides being detected in a few samples that were collected during the wet period. This can be attributed to the significant increase in household combustion during the dry winter season in South Africa. The regional impacts of household combustion from towns and cities within a 50 to $100 \mathrm{~km}$ radius will influence the air masses measured at Welgegund. A recent study indicated the regional impact of household combustion on black carbon in the north-eastern interior of South Africa [47], while the influence of household combustion on $\mathrm{PM}_{10}$ measured in the industrialised Western Bushveld Igneous Complex that is also one of the major source regions impacting Welgegund was also revealed [48].

The $\Sigma$ NRRFs of two specific nitrile compounds, i.e.,2,4-pentanedinitrile and cyanogen, which were also detected in other samples that were collected throughout the sampling period, were significantly higher in the $\mathrm{PM}_{1}$ size fraction in the sample collected on 10 May 2011. Cyanogen is a toxic compound, while Graedel et al. [49] indicated that the possible sources of cyanogen in the environment are vehicles, waste incineration, and tobacco smoke. 2,4-pentandinitrile is an aliphatic nitrile. Özel et al. [28] also identified a number of aliphatic nitriles using GCxGC-TOFMS in aerosol samples that were collected in an urban area, although 2,4-pentandinitrile was not specifically characterised.
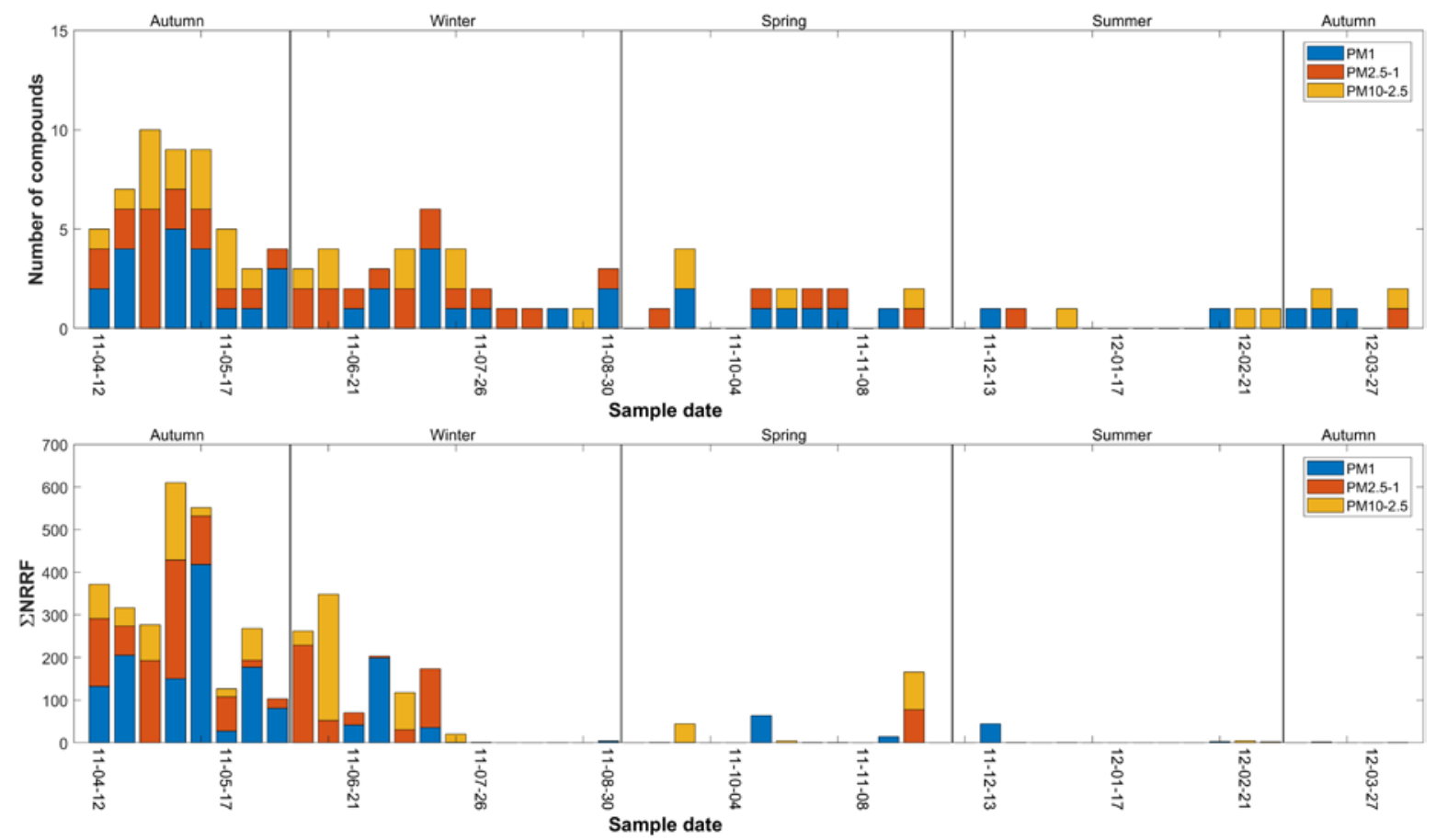

Figure 3. Total number of nitriles identified and their corresponding semi-quantified concentrations $(\Sigma N R R F s)$ in the three particle size fractions for each sample collected. 


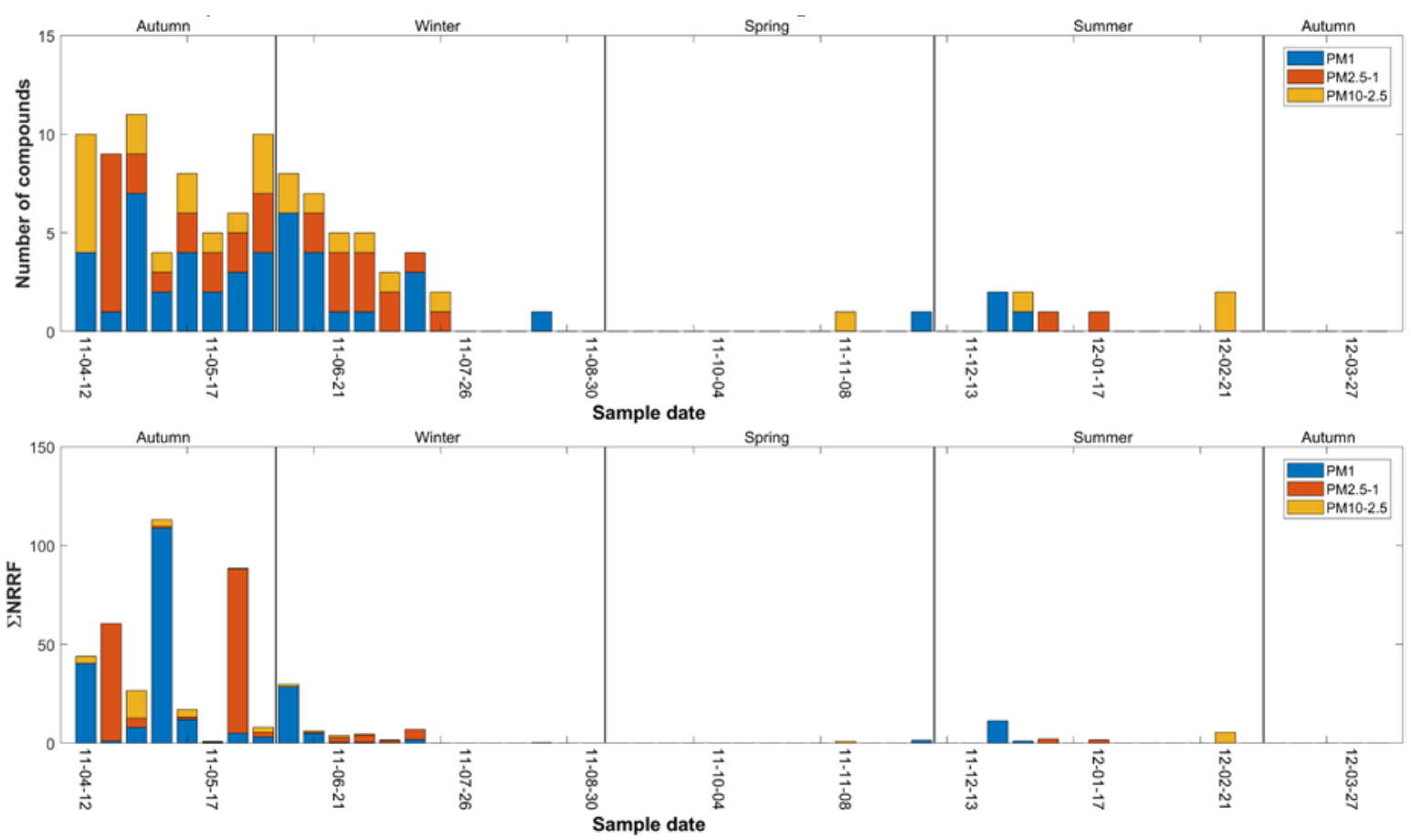

Figure 4. Total number of amides identified and their corresponding semi-quantified concentrations $(\Sigma N R R F s)$ in the three particle size fractions for each sample collected.

For the sample that was collected on 3 May 2011, the $\Sigma$ NRRF of amides in the $\mathrm{PM}_{1}$ size fraction was significantly higher, which was attributed to one specific amide compound, i.e., acetamide. Acetamide is the simplest amide species, which is generally used as an industrial solvent. This compound is listed by the US EPA as a hazardous pollutant and it was also characterised by Özel et al. [28] in urban aerosols. Relatively high semi-quantified concentrations were also determined for $\mathrm{N}$-methoxy-formamide in the $\mathrm{PM}_{2.5-1}$ size fraction in the sample collected on 24 May 2011. Formamides have a number of industrial and commercial uses, which include the manufacturing of agrichemical (fungicides) and pharmaceutical products. Although with significantly lower $\Sigma$ NRRFs, acetamide and $N$-methoxy-formide were also detected in other samples collected.

Urea is an amide compound with two $\mathrm{NH}_{2}$ groups that are bonded to the carbonyl functional group. According to Cornell et al. [50], the general ambient concentration of urea is $18 \mathrm{nmol} \mathrm{N} \mathrm{m}^{-3}$ in aerosols, while its concentration ranges between $<0.4$ and $10 \mu \mathrm{mol} \mathrm{N} \mathrm{dm}{ }^{-3}$ in precipitation. The major anthropogenic sources of urea are agricultural fertiliser and animal husbandry, while the end-product of mammalian metabolism is the main natural source of urea [50]. As indicated in Figure 1, very low semi-quantified concentrations of urea were determined while using GCxGC-TOFMS analysis. Urea was only tentatively identified in 13 samples that were mainly collected in the $\mathrm{PM}_{2.5-1}$ and $\mathrm{PM}_{10-2.5}$ size fractions. However, a relatively higher $\Sigma \mathrm{NRRF}$ value (32) was determined in the $\mathrm{PM}_{1}$ size fraction in the sample that was collected on 14 June 2011. Urea is generally a minor component of aerosol organic nitrogen [51]. However, urea can be a major component in rain water and water-soluble aerosols, depending on region [52].

\subsection{Pyridine Derivatives and Other Aromatic Heterocyclic Compounds}

42 heterocyclic pyridine derivatives and one other aromatic heterocyclic compound, i.e., 1 , 3.4-oxadiazole, were tentatively characterised in all three size fractions, which was the second highest number of species identified for an organic $\mathrm{N}$ functional group. In Figure 5, the total number of pyridine derivatives (and 1,3,4-oxadiazole) tentatively characterised and their corresponding $\sum$ NRRFs in each collected sample are presented. 1,3,4-oxadiazole was only characterised in the sample that was collected on 5 July 2011, which contributed to the relatively higher $\sum$ NRRFs in the $\mathrm{PM}_{2.5-1}$ 
size fraction. Oxadiazole isomers are considered to be derivatives from furans [53]. There are a number of sources of atmospheric furans (and dioxins), which include combustions processes (e.g., biomass burning), metal smelting and processing, chemical manufacturing, as well as biological and photochemical processes [54]. It is evident from Figure 5 that the higher total number of pyridine derivatives characterised and their associated $\sum$ NRRFs during the period from 12 April 2011 to 12 July 2011 corresponded to the period during which an increased total number of polar organic compounds and their associated $\sum$ NRRFs were determined, as indicated by Booyens et al. [30] (Appendix A). With the exception of three samples, no pyridine derivatives were tentatively characterised for samples that were collected from 19 July 2011 to 4 April 2012. The possible sources of pyridine derivatives at Welgegund include biomass burning, household combustion, and pesticides. Ma and Hays [55] characterised and quantified 14 heterocyclic aromatic N compounds while using GCxGC-TOFMS, which included pyridine derivatives from biomass burning aerosols. Aerosol samples were collected from a simulated agricultural fire in a test enclosure with rice crop residue being collected from a plantation in Sacramanto Valley, California. Forbes [56] indicated relatively high concentrations of heterocyclic $\mathrm{N}$-containing compounds in particulate emissions from household combustion in South Africa characterised with TD-GCxGC-TOFMS. Pyridine compounds that were measured at Welgegund could also be associated with pesticides [57] due to local and regional agricultural activities. From the observed temporal variability for pyridine derivatives it seems that regional open biomass burning and household combustion are most likely the major sources of these species. The regional source of these species is also reflected by these species occurring predominantly in the larger size fraction, i.e., $\mathrm{PM}_{2.5-1}$ (Figure $1 \mathrm{~b}$ ). The significantly higher $\sum \mathrm{NRRF}$ s determined for pyridine derivatives in samples collected on 29 April 2011 were mainly attributed to two species, i.e., 2,3,6-trimethyl-pyridine and 2-hydrazinopyridine.
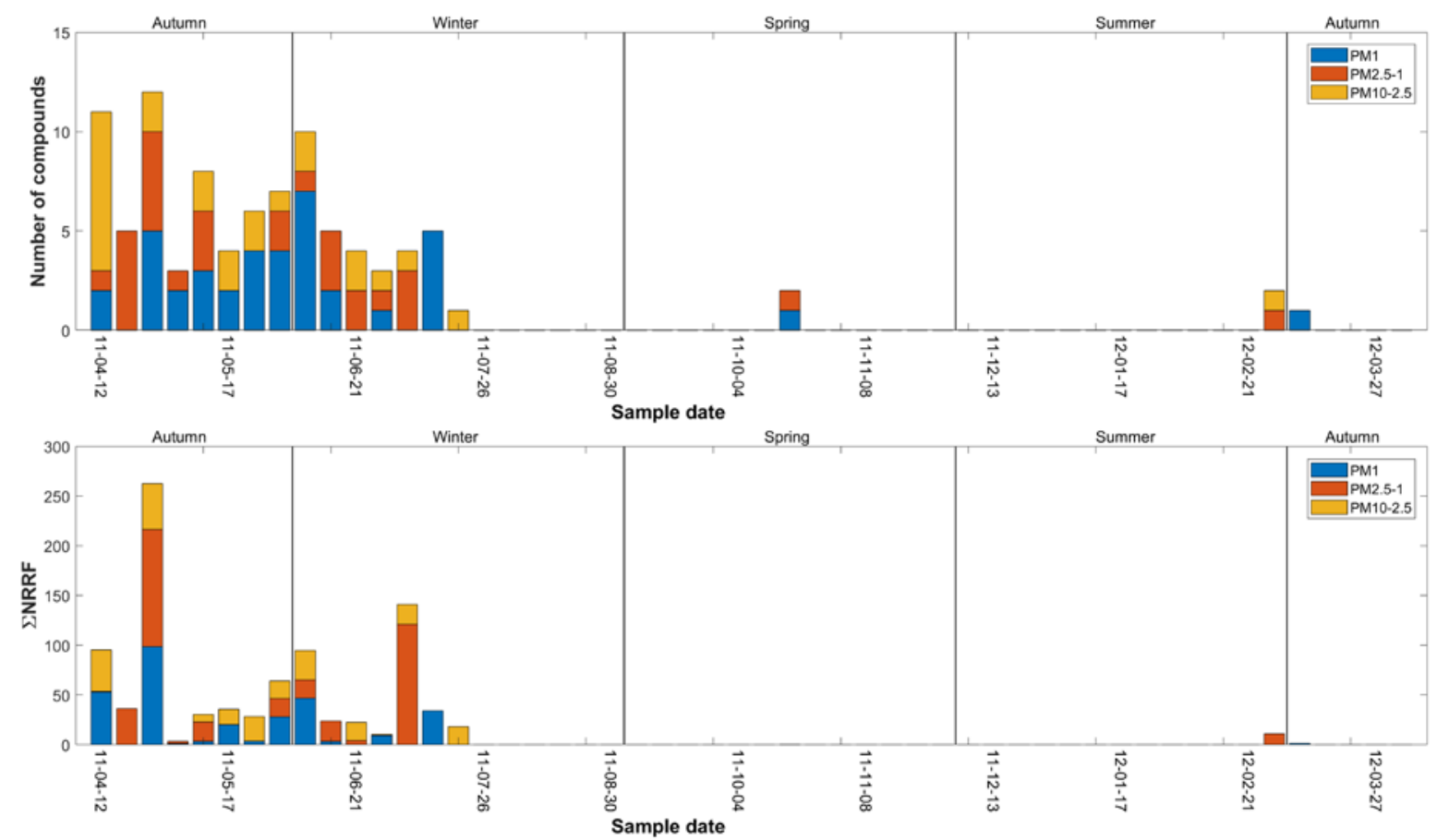

Figure 5. Total number of pyridine derivatives identified and their corresponding semi-quantified concentrations ( $\Sigma$ NRRFs) in the three particle size fractions for each sample collected.

\subsection{Other Organic N Species}

As indicated in Figure 1, the semi-quantified concentrations of amino acids, nitro- and nitroso compounds, imines, cyanates, isocyanates, and azo-compounds were very low. In addition, these species were detected in $\sim 25 \%$ or less of the samples. In Table 1 , the number of each of these species 
tentatively identified and their corresponding $\Sigma$ NRRFs are summarized. Azo compounds are not listed in the Table 1, since only one azo compound was detected in one collected sample. Each of these species are briefly discussed in subsequent paragraphs.

Table 1. Summary of organic $\mathrm{N}$ functional groups tentatively identified with very low abundancies.

\begin{tabular}{|c|c|c|c|c|c|c|c|c|c|c|c|c|c|}
\hline \multirow{2}{*}{$\begin{array}{c}\text { Sample } \\
\text { date }\end{array}$} & \multirow{2}{*}{$\begin{array}{c}\text { Size } \\
\text { fraction }\end{array}$} & \multicolumn{2}{|c|}{ Amino Acids } & \multicolumn{2}{|c|}{ Nitro } & \multicolumn{2}{|c|}{ Nitroso } & \multicolumn{2}{|c|}{ Imines } & \multicolumn{2}{|c|}{ Cyanantes } & \multicolumn{2}{|c|}{ Isocyanates } \\
\hline & & $\#$ & $\sum$ NRRF & $\#$ & $\sum$ NRRF & $\#$ & $\sum$ NRRF & $\#$ & $\sum$ NRRF & $\#$ & $\sum$ NRRF & $\#$ & $\sum$ NRRF \\
\hline \multirow[t]{3}{*}{$12 / 04 / 11$} & $\mathrm{PM}_{1}$ & & & 2 & 20.3 & & & & & & & & \\
\hline & $\mathrm{PM}_{2.5-1}$ & & & 1 & 12.4 & & & & & & & & \\
\hline & $\mathrm{PM}_{10-2.5}$ & & & 3 & 6.3 & & & & & & & & \\
\hline \multirow[t]{2}{*}{ 19/04/11 } & $\mathrm{PM}_{1}$ & & & & & & & 1 & 2.2 & & & & \\
\hline & $\mathrm{PM}_{2.5-1}$ & & & & & & & 1 & 3.7 & & & & \\
\hline \multirow[t]{3}{*}{$26 / 04 / 11$} & $\mathrm{PM}_{1}$ & & & 2 & 0.1 & & & 1 & 0.7 & & & & \\
\hline & $\mathrm{PM}_{2.5-1}$ & & & & & & & 1 & 1.8 & & & & \\
\hline & $\mathrm{PM}_{10-2.5}$ & & & & & & & 1 & 0.1 & & & & \\
\hline $17 / 05 / 11$ & $\mathrm{PM}_{2.5-1}$ & 1 & 3.9 & & & & & & & & & & \\
\hline \multirow[t]{2}{*}{$24 / 05 / 11$} & $\mathrm{PM}_{1}$ & & & & & & & 1 & 2.6 & & & & \\
\hline & $\mathrm{PM}_{10-2.5}$ & & & & & 1 & 48.1 & & & & & & \\
\hline $31 / 05 / 11$ & $\mathrm{PM}_{10-2.5}$ & & & & & 1 & 22.7 & & & & & & \\
\hline \multirow[t]{2}{*}{ 07/06/11 } & $\mathrm{PM}_{1}$ & & & 1 & $<0.1$ & & & 1 & 1.6 & & & & \\
\hline & $\mathrm{PM}_{2.5-1}$ & & & & & & & 1 & 1.0 & & & & \\
\hline $28 / 06 / 11$ & $\mathrm{PM}_{10-2.5}$ & & & 1 & 3.5 & & & & & & & & \\
\hline 05/07/11 & $\mathrm{PM}_{10-2.5}$ & & & & & & & 1 & 0.1 & & & & \\
\hline \multirow[t]{2}{*}{$12 / 07 / 11$} & $\mathrm{PM}_{1}$ & 1 & 2.0 & 1 & 0.1 & & & 1 & 0.4 & & & & \\
\hline & $\mathrm{PM}_{2.5-1}$ & & & & & & & & & & & 1 & 48.9 \\
\hline \multirow[t]{3}{*}{ 19/07/11 } & $\mathrm{PM}_{1}$ & & & & & & & & & & & 1 & 6.4 \\
\hline & $\mathrm{PM}_{2.5-1}$ & & & & & & & & & & & 1 & 30.9 \\
\hline & $\mathrm{PM}_{10-2.5}$ & & & & & & & & & & & 1 & 2.4 \\
\hline $26 / 07 / 11$ & $\mathrm{PM}_{10-2.5}$ & & & & & & & & & & & 1 & 1.6 \\
\hline $02 / 08 / 11$ & $\mathrm{PM}_{2.5-1}$ & & & 1 & 0.4 & & & & & & & & \\
\hline \multirow[t]{2}{*}{$16 / 08 / 11$} & $\mathrm{PM}_{1}$ & & & & & & & 1 & 0.5 & & & & \\
\hline & $\mathrm{PM}_{2.5-1}$ & & & & & & & & & 1 & 0.5 & & \\
\hline $23 / 08 / 11$ & $\mathrm{PM}_{1}$ & & & & & & & 1 & 5.0 & 1 & 1.1 & & \\
\hline \multirow[t]{2}{*}{$30 / 08 / 11$} & $\mathrm{PM}_{2.5-1}$ & & & & & & & & & 1 & 1.6 & & \\
\hline & $\mathrm{PM}_{10-2.5}$ & & & & & & & 1 & $<0.1$ & & & & \\
\hline $11 / 10 / 11$ & $\mathrm{PM}_{2.5-1}$ & & & & & 1 & 0.2 & & & & & & \\
\hline $18 / 10 / 11$ & $\mathrm{PM}_{1}$ & & & & & & & 1 & 0.4 & & & & \\
\hline 08/11/11 & $\mathrm{PM}_{1}$ & & & & & & & 1 & 0.1 & & & & \\
\hline \multirow[t]{2}{*}{ 29/11/11 } & $\mathrm{PM}_{2.5-1}$ & & & 1 & 0.9 & & & & & & & & \\
\hline & $\mathrm{PM}_{10-2.5}$ & & & & & & & 1 & 0.5 & & & & \\
\hline 20/12/11 & $\mathrm{PM}_{1}$ & & & 1 & 0.1 & & & 1 & 0.6 & & & & \\
\hline $10 / 01 / 12$ & $\mathrm{PM}_{2.5-1}$ & 1 & 1.6 & & & & & & & & & & \\
\hline \multirow[t]{2}{*}{$17 / 01 / 12$} & $\mathrm{PM}_{1}$ & & & & & & & & & & & 1 & 38.5 \\
\hline & $\mathrm{PM}_{10-2.5}$ & & & 1 & 0.4 & & & & & & & & \\
\hline $24 / 01 / 12$ & $\mathrm{PM}_{1}$ & & & 1 & 0.3 & & & & & & & & \\
\hline $31 / 01 / 12$ & $\mathrm{PM}_{1}$ & & & 1 & 0.4 & & & & & & & & \\
\hline \multirow[t]{2}{*}{$21 / 02 / 12$} & $\mathrm{PM}_{2.5-1}$ & & & & & & & 1 & 1.7 & & & & \\
\hline & $\mathrm{PM}_{10-2.5}$ & & & 1 & 2.9 & & & & & & & & \\
\hline
\end{tabular}


Table 1. Cont.

\begin{tabular}{lllllllll}
\hline Sample & Size & Amino Acids & \multicolumn{2}{c}{ Nitro } & Nitroso & Imines & Cyanantes & Isocyanates \\
\hline $\mathbf{2 8 / 0 2 / 1 2}$ & $\mathrm{PM}_{1}$ & & & 1 & 0.2 & & \\
\hline & $\mathrm{PM}_{10-2.5}$ & 1 & 4.3 & 1 & 0.2 & & \\
\hline $\mathbf{1 3 / 0 3 / 1 2}$ & $\mathrm{PM}_{2.5-1}$ & 1 & 1.3 & & & & & \\
\hline $\mathbf{2 0 / 0 3 / 1 2}$ & $\mathrm{PM}_{2.5-12.5-1} 1$ & 1.9 & & & & & \\
\hline $\mathbf{2 7 / 0 3 / 1 2}$ & $\mathrm{PM}_{10-2.5}$ & 1 & 2.2 & & & & & \\
\hline $\mathbf{0 3 / 0 4 / 1 2}$ & $\mathrm{PM}_{10-2.5}$ & 1 & 16.5 & & & & 2.0 & \\
\hline
\end{tabular}

\subsubsection{Amino Acids}

Amino acids are considered to be an important group of atmospheric organic nitrogen compounds. These species predominantly occur in condensed phase in the atmosphere due to their low vapour pressures [11] and they are typically present in rainwater [50], fog [58] and dew [59]. Zhang et al. [60], for instance, indicated that amino acids contributed $<1 \%$ of total $\mathrm{PM}_{2.5}$ mass at Davis, California, while Mace et al. [61] indicated that amino acids contribute $~ 53 \%$ of organic $\mathrm{N}$ in rain water. Only one amino acid, i.e., glycine, was tentatively identified in eight aerosol samples that were collected at Welgegund (Table 1) mainly in the $\mathrm{PM}_{2.5-12.5-1}$ and $\mathrm{PM}_{10-2.5}$ size fractions. The corresponding $\Sigma \mathrm{NRRF}$ of glycine was also very low, with the exception of slightly higher $\Sigma \mathrm{NRRF}$ in the $\mathrm{PM}_{10-2.5}$. size fraction for one sample that was collected on 4 April 2012. Glycine is commonly used in animal feed, which could be a possible source thereof on a commercial farm.

\subsubsection{Nitro- and Nitroso Compounds}

Nitro- and nitroso compounds are secondary pollutants, which can be formed in the atmosphere through the photochemical gas phase reactions between volatile organic compounds, $\mathrm{NO}_{\mathrm{x}}$ and ozone [62], while the concentrations of these species are generally low. These species could potentially be of toxicological importance with a few nitro- and nitroso compounds being listed on the hazardous air pollution list of the Environmental Protection Agency (EPA) [15,63]. As indicated in Table 1, only one nitro-organic species was tentatively identified in the 11 samples collected (with the exception of two samples collected during the first three weeks), which occurred in most instances in the $\mathrm{PM}_{1}$ size fraction. Only one nitroso species was also tentatively characterised in each of the three samples collected on 24 May 2011, 31 May 2011, and 11 October 2011 mainly in the $\mathrm{PM}_{10-2.5}$ size fractions. The corresponding $\Sigma$ NRRFs of the nitro species tentatively identified in samples that were collected after the first sampling week were also very low. The $\Sigma$ NRRFs of the nitro compounds tentatively identified on 12 April 2011 were significantly higher, which was mainly attributed to the species 2-nitrobutane. Two nitroso species were tentatively identified, i.e., $N$-nitroso- $N$-methyl-(1-phenyl)-ethylamine and $N$-nitroso-methyl-ethylamine. For the samples collected on 24 and 31 May 2011, significantly higher $\Sigma$ NRRFs were determined for $N$-nitroso-methyl-ethylamine in the $\mathrm{PM}_{10-2.5}$ size fraction. Most of the nitrosamine species are considered to be carcinogenic and $\mathrm{N}$-nitroso-methyl-ethylamine are listed on the US EPA hazardous pollutant lists. Very high levels of $N$-nitroso-dimethylamine, which is related to $N$-nitroso-methyl-ethylamine, have been determined in soils, which was attributed to the use of triazine herbicides that react with nitrogenous fertilisers [64]. Özel et al. [28] also characterised $\mathrm{N}$-nitroso-dimethylamine while using GCxGC-TOFMS in urban samples. Atmospheric concentrations of nitro and nitroso species are generally low [64], since most of these species are considered to be semi-volatile organic compounds [63]. No organic nitrate species were tentatively characterised, which could be attributed to thermal decomposition during analysis [15].

\subsubsection{Imines}

Imines are formed in the atmosphere through the reaction of ammonia with carbonyls that form the intermediate primary imines and amines products, which further react with carbonyls to form 
more stable secondary imines [65]. Imine species occur in the formation mechanism of brown carbon, but they have not been observed in ambient measurements [66,67]. It is evident from Table 1 that very low semi-quantified concentrations of only one imine compound was tentatively identified in each of the size fractions for most of the 15 samples wherein the imine species were tentatively characterised, which was $N$-(1,2-diphenylethyl) methanimine.

\subsubsection{Cyanates and Isocyanates}

Only one cyanate compound, i.e., ethyl ester cyanic acid, was found in each of three samples collected with very low $\Sigma$ NRRFs, while one isocyanate species was tentatively characterised in four samples collected, i.e., cyclohexyl isocyanate (Table 1). The samples collected on 12 July 2011 and 17 January 2012 had significantly higher $\Sigma$ NRRFs of cyclohexyl isocyanate in the $\mathrm{PM}_{2.5-1}$ and $\mathrm{PM}_{1}$ size fractions, respectively, as compared to the other samples in which these species were detected in any size fraction. Cyclohexyl isocyanate is used in the manufacturing of pharmaceutical and agricultural chemicals. Isocyanates are generally considered to be harmful to the respiratory system, while exposure to isocyanate is identified as one of the most common causes of occupational asthma $[68,69]$.

\subsubsection{Azo Compounds}

Only one azo compound was tentatively identified in a sample that was collected on 27 December 2011, i.e., 1, 2, 3-thiadiazole in the $\mathrm{PM}_{2.5-1}$ size fraction, which had a $\Sigma$ NRRF of $\sim 17$. Thiadiazole derivatives have numerous applications in agricultural, pharmaceutical, and material chemistry. These compounds are widely used in pesticides, which include herbicides, fungicides, insecticides, bactericides, and plant-growth regulators [70].

\section{Summary and Conclusions}

In total, 135 atmospheric organic $\mathrm{N}$ compounds were tentatively characterised and semi-quantified while using GCxGC-TOFMS for ambient atmospheric aerosols that were collected at a savanna-grassland region in the interior of South Africa for one year. According to the knowledge of the authors, this is the first time that atmospheric particulate organic $\mathrm{N}$ species were identified and semi-quantified for southern Africa, while, in general, only a few studies have been globally conducted utilising GCxGC-TOFMS to characterise atmospheric organic N. In this study, amines, nitriles, amides, urea, pyridine derivatives, amino acids, nitro- and nitroso compounds, imines, cyanates and isocyanates, and azo compounds were tentatively characterised and semi-quantified. The most abundant species tentatively identified were amines, while nitrile compounds were the second most abundant species. Relatively higher semi-quantified concentrations were also determined for the amides and pyridine derivatives. The semi-quantified concentrations of the other organic $\mathrm{N}$ functional groups were very low, with most of these organic $\mathrm{N}$ groups only consisting of one species in each of the samples collected. The temporal variations of amines, nitriles, amides and pyridine derivatives were similar to that observed for all of the polar organic compounds, i.e., a period between 12 April 2011 and 12 July 2011 (mid-autumn to mid-winter) coinciding with the dry season, with elevated semi-quantified concentrations of these species. These temporal variations were mainly attributed to meteorological parameters and the influence of local open biomass burning, as indicated in Booyens et al. [30], for all polar organic aerosols. Anthropogenic sources in the major source regions impacting air masses measured at Welgegund, as well as regional agricultural activities, were considered as the major sources of amines, while the regional influence of household combustion was considered the main source of nitriles, amides, and pyridine derivatives. Most of the other organic $\mathrm{N}$ functional groups had very low abundancies, which were most likely related to the influence of local and regional agricultural activities.

As mentioned, the significance of amines to secondary particle formation has been indicated in recent studies e.g., Almeida et al. [18]. In this study, amine compounds were considerably more abundant than any of the other organic $\mathrm{N}$ aerosols. It is also of significance that amines comprised $\sim 10 \%$ of all organic aerosols that were tentatively characterised in the $\mathrm{PM}_{1}$ size fraction, which is the 
relevant size fraction with regard to new particle formation. Therefore, when considering that recent studies have indicated record-high frequencies of nucleation events in this region [42,43], these species are important. Amines can also be considered to be important in rain water chemistry for a region for which an increase in rain water $\mathrm{pH}$ was observed during the last number of years [41]. The relative abundance of nitriles, amides, and pyridine derivatives reflects the large-scale influence of household combustion in the region and its impacts on general air quality and climate change. Emissions that are associated with household combustion for space heating significantly increase during winter in South Africa. Although very low semi-quantified concentrations of other particulate organic $\mathrm{N}$ species were determined, these species can have other hazardous environmental impacts. A few imine species were also detected, which, as previously mentioned, are important in the formation mechanism of brown carbon. However, very low semi-quantified concentrations were determined. Furthermore, although some of the species tentatively identified can be considered as toxic in the environment, the concentrations of these species were very low throughout the sampling period with low risk associated with these compounds.

Although a large number of $\mathrm{N}$ compounds could be tentatively characterised and semi-quantified, it is recommended that future studies should attempt to characterise even more particulate organic $\mathrm{N}$ species with increased certainty, as well as to absolutely quantify compounds or at least specific compounds that are identified as problematic.

Author Contributions: W.B., P.G.V.Z. and J.P.B. were the principle investigators in this study. P.G.V.Z. and J.P.B. were project leaders of the study and wrote the manuscript. W.B. conducted this study as part of her Ph.D degree, as well as performed most of the experimental work and data processing. P.G.V.Z. and J.P.B. were also study leaders of the Ph.D. M.J. and V.V. assisted in sample collection and data interpretation. J.R.-J. and M.K. (Matias Kopperi) assisted with GCxGC-MS analysis. M.-L.R., M.K. (Markku Kulmala) and L.L. made conceptual contributions.

Funding: This research was funded by the University of Helsinki, the Finnish Meteorological Institute, the North-West University and the National Research Foundation (NRF). Opinions expressed and conclusions arrived at are those of the authors and are not necessarily to be attributed to the NRF. V. Vakkari is a beneficiary of an AXA Research Fund postdoctoral grant (grant no. 272041).

Acknowledgments: The authors wish to thank Diederik and Jackie Hattingh and their family who are the owners of the commercial farm on which the Welgegund measurement station is situated.

Conflicts of Interest: The authors declare no conflict of interest. The funders had no role in the design of the study; in the collection, analyses, or interpretation of data; in the writing of the manuscript, or in the decision to publish the results.

\section{Appendix A}

Table A1. Average $\sum$ NRRFs of amines, nitriles, amides and pyridine derivatives measured during the three different periods indicated by Booyens et al. [30] for all polar organic compounds.

\begin{tabular}{lcccc}
\hline & Amines & Nitriles & Amides & Pyridine Derivatives \\
\hline $12 / 04 / 2011-12 / 07 / 2011$ & $323 \pm 236$ & $272 \pm 162$ & $29 \pm 35$ & $63 \pm 69$ \\
$02 / 08 / 2011-04 / 10 / 2011$ & $2 \pm 4$ & $6 \pm 13$ & $0 \pm 0$ & $2 \pm 5$ \\
$11 / 10 / 2011-04 / 04 / 2012$ & $31 \pm 42$ & $12 \pm 35$ & $1 \pm 2$ & $0 \pm 2$ \\
\hline
\end{tabular}

\section{References}

1. Kingston, E.; Bowersox, V.; Zorrilla, G. Nitrogen in the Nation's Rain. In National Atmospheric Deposition Program; Illinois State Water Survey: Champaign, IL, USA, 2000; Available online: http://nadp.sws.uluc.edu (accessed on 25 July 2017).

2. Altieri, J.D.; Turpin, B.J.; Seitzinger, S.P. Composition of dissolved organic nitrogen in continental precipitation investigated by ultra-high-resolution FT-ICR mass spectrometry. Environ. Sci. Technol. 2009, 43, 6950-6955. [CrossRef] [PubMed]

3. Jickells, T.; Baker, A.R.; Cape, J.N.; Cornell, S.E.; Nemitz, E. The cycling of organic nitrogen through the atmosphere. Philos. Trans. R. Soc. B 2013, 368, 1621. [CrossRef] [PubMed] 
4. Cape, J.N.; Cornell, S.E.; Jickells, T.D.; Nemitz, E. Organic nitrogen in the atmosphere-Where does it come from? A review of sources and methods. Atmos. Res. 2011, 102, 30-48. [CrossRef]

5. Cornell, S. Atmospheric nitrogen deposition: Revisiting the question of the importance of the organic component. Environ. Pollut. 2011, 159, 2214-2222. [CrossRef] [PubMed]

6. Borduas, N. The Atmospheric Fate of Organic Nitrogen Compounds. Ph.D. Thesis, University of Toronto, Toronto, ON, Canada, November 2015.

7. Mace, K.A.; Artaxo, P.; Duce, R.A. Water-soluble organic nitrogen in Amazon Basin aerosols during the dry (biomass burning) and wet seasons. J. Geophys. Res. Atmos. 2003, 108, 4512. [CrossRef]

8. Zamora, L.M.; Prospero, J.M.; Hansell, D.A. Organic nitrogen in aerosols and precipitation at Barbados and Miami: Implications regarding sources, transport and deposition to the western subtropical Atlantic. J. Geophys. Res. Atmos. 2011, 116, D20309. [CrossRef]

9. Mace, K.A.; Duce, R.A.; Tindale, N.W. Organic nitrogen in rain and aerosol at Cape Grimm, Tasmania, Australia. J. Geophys. Res. Atmos. 2003, 108, 4338. [CrossRef]

10. Chen, H.-Y.; Chen, L.-D.; Chiang, Z.-Y.; Hung, C.-C.; Lin, F.-J.; Chou, W.-C.; Gong, G.-C.; Liang, L.-C. Size fractionation and molecular composition of water soluble inorganic and organic nitrogen in aerosols of a coastal environment. J. Geophys. Res. Atmos. 2010, 115, D22307. [CrossRef]

11. Ge, X.; Wexler, A.S.; Clegg, S.L. Atmospheric amines-Part, I. A review. Atmos. Environ. 2011, 45, 524-546. [CrossRef]

12. Gorzelka, K.; Galloway, J.N. Amine nitrogen in the atmospheric environment over the North Atlantic Ocean. Glob. Biogeochem. Cycles 1990, 4, 309-333. [CrossRef]

13. Neff, J.C.; Holland, E.A.; Dentener, F.J.; McDowell, W.H.; Russell, K.M. The origin, composition and rates of organic nitrogen deposition: A missing piece of the nitrogen cycle? Biogeochemistry 2002, 57, 99-136. [CrossRef]

14. Arey, J.; Zielinska, B.; Harger, W.P.; Atkinson, R.; Winer, A.M. The Contribution of Nitrofluoranthenes and Nitropyrenes to the Mutagenic Activity of Ambient Particulate Organic-Matter Collected in Southern-California. Mutat. Res. 1988, 207, 45-51. [CrossRef]

15. Özel, M.Z.; Ward, M.W.; Hamilton, J.F.; Lewis, A.C.; Raventos-Duran, T.; Harrison, R.M. Analysis of Organic Nitrogen Compounds in Urban Aerosol Samples Using GCxGC-TOF/MS. Aerosol Sci Technol. 2010, 44, 109-116. [CrossRef]

16. Lee, D.; Wexler, A.S. Atmospheric amines-Part III: Photochemistry and toxicity. Atmos. Environ. 2013, 71, 95-103. [CrossRef]

17. Facchini, M.C.; Decesari, S.; Rinaldi, M.; Carbone, C.; Finessi, E.; Mircea, M.; Fuzzi, S.; Moretti, F.; Tagliavini, E.; Ceburnis, D.; et al. Important source of marine secondary organic aerosol from biogenic amines. Environ. Sci. Technol. 2008, 42, 9116-9121. [CrossRef]

18. Almeida, J.; Schobesberger, S.; Kürten, A.; Ortega, I.K.; Kupiainen-Määttä, O.; Praplan, A.P.; Adamov, A.; Amorim, A.; Bianchi, F.; Breitenlechner, M.; et al. Molecular understanding of sulphuric acid-Amine particle nucleation in the atmosphere. Nature 2013, 502, 359-363. [CrossRef]

19. Galloway, M.M.; Chhabra, P.S.; Chan, A.W.H.; Surratt, J.D.; Flagan, R.C.; Seinfeld, J.H.; Keutsch, F.N. Glyoxal uptake on ammonium sulphate seed aerosol: Reaction products and reversibility of uptake under dark and irradiated conditions. Atmos. Chem. Phys. Discuss. 2008, 8, 20799-20838. [CrossRef]

20. Nozière, B.; Dziedzic, P.; Córdova, A. Products and kinetics of the liquid-phase reaction of glyoxal catalyzed by ammonium ions (NH4(p)). J. Phys. Chem. A 2009, 113, 231-237. [CrossRef]

21. Andreae, M.O.; Gelencsér, A. Black carbon or brown carbon? The nature of light-absorbing carbonaceous aerosols. Atmos. Chem. Phys. Discuss. 2006, 6, 3419-3463. [CrossRef]

22. Climate Change 2013. The Physical Science Basis. In Third Assessment of the Intergovernmental Panel on Climate Change (IPCC); Cambridge University Press: New York, NY, USA, 2013.

23. Laskin, J.; Laskin, A.; Nizkorodov, S.A.; Roach, P.; Eckert, P.; Gilles, M.K.; Wang, B.; Lee, H.J.; Hu, Q. Molecular selectivity of brown carbon chromophores. Environ. Sci. Technol. 2014, 48, 12047-12055. [CrossRef]

24. Lin, G.X.; Penner, J.E.; Flanner, M.G.; Sillman, S.; Xu, L.; Zhou, C. Radiative forcing of organic aerosol in the atmosphere and on snow: Effects of SOA and brown carbon. J. Geophys. Res. Atmos. 2014, 119, 7453-7476. [CrossRef]

25. Lewis, A.C.; Carslaw, N.; Marriott, P.J.; Kinghorn, R.M.; Morrison, P.; Lee, A.L.; Bartle, K.D.; Pilling, M.J. A larger pool of ozone-forming carbon compounds in urban atmospheres. Nature 2000, 405, 778-781. [CrossRef] 
26. Welthagen, W.; Schnelle-Kreis, J.; Zimmermann, R. Search criteria and rules for comprehensive two-dimensional gas chromatography-time-of-flight-mass spectrometry analysis of airborne particulate matter. J. Chromatogr. A 2003, 1019, 233-249. [CrossRef]

27. Alam, M.S.; West, C.E.; Scarlett, A.G.; Rowland, S.J.; Harrison, R.M. Application of 2D-GCMS reveals many industrial chemicals in airborne particulate matter. Atmos. Environ. 2013, 65, 101-111. [CrossRef]

28. Özel, M.Z.; Hamilton, J.F.; Lewis, A.C. New sensitive and quantitative analysis method for organic nitrogen compounds in urban aerosol samples. Environ. Sci. Technol. 2011, 45, 1497-1505. [CrossRef]

29. Booyens, W.; Van Zyl, P.G.; Beukes, J.P.; Ruiz-Jimenez, J.; Kopperi, M.; Riekkola, M.-L.; Josipovic, M.; Venter, A.D.; Jaars, K.; Laakso, L.; et al. Size-resolved characterisation of organic compounds in atmospheric aerosols collected at Welgegund, South Africa. J. Atmos. Chem. 2015, 72, 43-64. [CrossRef]

30. Booyens, W.; Beukes, J.P.; Van Zyl, P.G.; Ruiz-Jimenez, J.; Kopperi, M.; Riekkola, M.-L.; Josipovic, M.; Vakkari, V.; Laakso, L. Seasonal assessment of organic aerosol compounds characterized at Welgegund, South Africa. J. Atmos. Chem. 2019, 76, 89-113. [CrossRef]

31. Petäjä, T.; Vakkari, V.; Pohja, T.; Nieminen, T.; Laakso, H.; Aalto, P.P.; Keronen, P.; Siivola, E.; Kerminen, V.-M.; Kulmala, M.; et al. Transportable aerosol characterization trailer with trace gas chemistry: Design, instruments and verification. Aerosol Air Qual. Res. 2013, 13, 421-435. [CrossRef]

32. Beukes, J.P.; Venter, A.D.; Josipovic, M.; Van Zyl, P.G.; Vakkari, V.; Jaars, K.; Dunn, M.; Laakso, L. Automated Continuous Air Monitoring. In Monitoring of Air Pollutants-Samling, Sample, Preparation and Analytical Techniques, 1st ed.; Forbes, P., Ed.; Elsevier: Amsterdam, The Netherlands, 2015; pp. 183-208.

33. Räsänen, M.; Aurela, M.; Vakkari, V.; Beukes, J.P.; Tuovinen, J.-P.; Van Zyl, P.G.; Josipovic, M.; Venter, A.D.; Jaars, K.; Siebert, S.J.; et al. Carbon balance of a grazed savanna grassland ecosystem in South Africa. Biogeosciences 2017, 14, 1039-1054.

34. Jaars, K.; Van Zyl, P.G.; Beukes, J.P.; Hellén, H.; Vakkari, V.; Josipovic, M.; Venter, A.D.; Räsänen, M.; Knoetze, L.; Cilliers, D.P.; et al. Measurements of biogenic volatile organic compounds at a grazed savannah grassland agricultural landscape in South Africa. Atmos. Chem. Phys. 2016, 16, 15665-15688. [CrossRef]

35. Jaars, K.; Beukes, J.P.; Van Zyl, P.G.; Venter, A.D.; Josipovic, M.; Pienaar, J.J.; Vakkari, V.; Aaltonen, H.; Laakso, H.; Kulmala, M.; et al. Ambient aromatic hydrocarbon measurements at Welgegund, South Africa. Atmos. Chem. Phys. 2014, 14, 7075-7089.

36. Ruiz-Jimenez, J.; Parshintsev, J.; Laitinen, T.; Hartonen, K.; Riekkola, M.-L.; Petäjä, T.; Virkkula, A.; Kulmala, K. A complete methodology for the reliable collection, sample preparation, separation and determination of organic compounds in ultrafine $30 \mathrm{~nm}, 40 \mathrm{~nm}$ and $50 \mathrm{~nm}$ atmospheric aerosol particles. Anal. Methods 2011, 3, 2501-2509. [CrossRef]

37. Ruiz-Jimenez, J.; Parshintsev, J.; Laitinene, T.; Hartonen, K.; Riekkola, M.; Petäjä, T.; Kulmala, M. Comprehensive two-dimensional gas chromatography, a valuable technique for screening and semiquantification of different chemical compounds in ultrafine $30 \mathrm{~nm}$ and $50 \mathrm{~nm}$ aerosol particles. J. Environ. Monit. 2011, 13, 2994-3003. [CrossRef]

38. Ochiai, N.; Ieda, S.; Sasamoto, K.; Fushimi, A.; Hasegawa, S.; Tanabe, K.; Kobayashi, S. Characterization of Organic Compounds in Atmospheric Nanoparticles by Thermal Extraction-Comprehensive Two-Dimensional Gas Chromatography (gcxgc) in Combination with Selective Detection, Mass Spectrometry and Accurate Mass Detection. In Global Analytical Solutions; Gerstel: Mülheim an der Ruhr, Germany, 2007.

39. Schnelle-Kreis, J.; Welthagen, W.; Sklorz, M.; Zimmermann, R. Application of direct thermal desorption gas chromatography and comprehensive two-dimensional gas chromatography coupled to time of flight mass spectrometry for analysis of organic compounds in ambient aerosol particles. J. Sep. Sci. 2005, 28, 1648-1657. [CrossRef]

40. Murphy, S.M.; Sorooshian, A.; Kroll, J.H.; Ng, N.L.; Chhabra, P.; Tong, C.; Surratt, J.D.; Knipping, E.; Flagan, R.C.; Seinfeld, J.H. Secondary aerosol formation from atmospheric reactions of aliphatic amines. Atmos. Chem. Phys. 2007, 7, 2313-2337. [CrossRef]

41. Conradie, E.H.; Van Zyl, P.G.; Pienaar, J.J.; Beukes, J.P.; Galy-Lacaux, C.; Venter, A.D.; Mkhatshwa, G.V. The chemical composition and fluxes of atmospheric wet deposition at four sites in South Africa. Atmos. Environ. 2016, 146, 113-131. [CrossRef]

42. Vakkari, V.; Beukes, J.P.; Laakso, H.; Mabaso, D.; Pienaar, J.J.; Kulmala, M.; Laakso, L. Long-term observations of aerosol size distributions in semi-clean and polluted savannah in South Africa. Atmos. Chem. Phys. 2013, 13, 1751-1770. [CrossRef] 
43. Hirsikko, A.; Vakkari, V.; Tiitta, P.; Manninen, H.E.; Gagne, S.; Laakso, H.; Kulmala, M.; Mirme, M.; Mirme, S.; Mabaso, D.; et al. Characterisation of sub-micron particle number concentrations and formation events in the western Bushveld Igneous Complex, South Africa. Atmos. Chem. Phys. 2012, 12, 3951-3967. [CrossRef]

44. Simoneit, B.R.T.; Rushdi, A.I.; bin Abas, M.R.; Didyk, B.M. Alkyl amides and nitriles as novel tracers for biomass burning. Environ. Sci. Technol. 2003, 37, 16-21. [CrossRef]

45. Barsanti, K.C.; Pankow, J.F. Thermodynamics of the formation of atmospheric organic particulate matter 514 by accretion reactions-Part 3: Carboxylic and dicarboxylic acids. Atmos. Environ. 2006, 40, 6676-6686. [CrossRef]

46. Nielsen, C.J.; Herrmann, H.; Weller, C. Atmospheric chemistry and environmental impact of the use of 595 amines in carbon capture and storage (CCS). Chem. Soc. Rev. 2012, 41, 6684-6704. [CrossRef]

47. Chiloane, K.E.; Beukes, J.P.; Van Zyl, P.G.; Maritz, P.; Vakkari, V.; Josipovic, M.; Venter, A.D.; Jaars, K.; Tiitta, P.; Kulmala, M.; et al. Spatial, temporal and source contribution assessments of black carbon over the northern interior of South Africa. Atmos. Chem. Phys. 2017, 17, 6177-6196. [CrossRef]

48. Venter, A.D.; Vakkari, V.; Beukes, J.P.; Van Zyl, P.G.; Laakso, H.; Mabaso, D.; Tiitta, P.; Josipovic, M.; Kulmala, M.; Pienaar, J.J.; et al. An air quality assessment in the industrialised western Bushveld Igneous Complex, South Africa. S. Afr. J. Sci. 2012, 108, 10. [CrossRef]

49. Graedel, T.E.; Hawkins, D.T.; Claxton, L.D. Atmospheric Chemical Compounds: Sources, Occurrence and Bioassay; Academic Press: Orlando, FL, USA, 1986; pp. 383-435.

50. Cornell, S.; Jickells, T.; Cape, J.N.; Rowland, A.; Duce, R. Organic nitrogen deposition on land and coastal environments: A review of methods and data. Atmos. Environ. 2003, 37, 2173-2191. [CrossRef]

51. Cornell, S.E.; Jickells, T.D.; Thornton, C.A. Urea in rainwater and atmospheric aerosol. Atmos. Environ. 1998, 32, 1903-1910. [CrossRef]

52. Cornell, S.; Mace, K.; Coeppicus, S.; Duce, R.; Huebert, B.; Jickells, T.; Zhuang, L.-Z. Organic nitrogen in Hawaiian rain and aerosol. J. Geophys. Res. Atmos. 2001, 106, 7973-7983. [CrossRef]

53. Bala, S.; Kamboj, S.; Kajal, A.; Vipin Saini, V.; Prasad, D.N. 1,3,4-Oxadiazole Derivatives: Synthesis, Characterization, Antimicrobial Potential, and Computational Studies. BioMed Res. Int. 2014, 172791. [CrossRef]

54. Relvas, H.; Lopes, M.; Coutinho, M. Portuguese inventory of dioxins and furans atmospheric emissions. Chemosphere 2013, 93, 1569-1577. [CrossRef]

55. Ma, Y.; Hays, M.D. Thermal extraction-two-dimensional gas chromatography-mass spectrometry with heart-cutting for nitrogen heterocyclic in biomass burning aerosols. J. Chromatogr. A 2008, 1200, 228-234. [CrossRef]

56. Forbes, P.B.C. Particle emissions from household fires in South Africa. Published in Air Pollution XX. WIT Trans. Ecol. Environ. 2012, 157, 445-456.

57. Atkinson, M.J. Rates of phosphate uptake by coral reef flat communities. Limnol. Oceanogr. 1987, 32, 426-435. [CrossRef]

58. Zhang, Q.; Anastasio, C. Chemistry of fog waters in California's Central Valley-Part 3: Concentrations and speciation of organic and inorganic nitrogen. Atmos. Environ. 2001, 35, 5629-5643. [CrossRef]

59. Scheller, E. Amino acids in dew-Origin and seasonal variation. Atmos. Environ. 2001, 35, $2179-2192$. [CrossRef]

60. Zhang, Q.; Anastasio, C.; Jimenez-Cruz, M. Water-soluble organic nitrogen in atmospheric fine particles (PM2. 5) from northern California. J. Geophys. Res. Atmos. 2002, 107, 4112. [CrossRef]

61. Mace, K.A.; Kubilay, N.; Duce, R.A. Organic nitrogen in rain and aerosol in the eastern Mediterranean atmosphere: An association with atmospheric dust. J. Geophys. Res. Atmos. 2003, 108, 4320. [CrossRef]

62. Ding, Y.; Cui, W.; Cui, W.; Eatough, D.J. Fine particulate N-nitroso and nitrite organic compounds in the atmosphere. Appl. Occup. Environ. Hyg. 1998, 13, 432-438. [CrossRef]

63. Ding, Y.; Lee, M.L.; Eatough, D.J. The determination of total nitrite and N-nitroso compounds in atmospheric samples. Int. J. Environ. Anal. Chem. 1998, 69, 243-255. [CrossRef]

64. Wexler, P. Encyclopaedia of Toxicology, 2nd ed.; Academic Press: Orlando, FL, USA, 2005.

65. Laskin, A.; Laskin, J.; Nizkorodov, S.A. Chemistry of atmospheric brown carbon. Chem. Rev. 2015, 115, 4335-4382. [CrossRef]

66. Zhao, R.; Lee, A.K.Y.; Huang, L.; Li, X.; Yang, F.; Abbatt, J.P.D. Photochemical processing of aqueous atmospheric brown carbon. Atmos. Chem. Phys. 2015, 15, 6087-6100. [CrossRef] 
67. Kampf, C.J.; Filippi, A.; Zuth, C.; Hoffmann, T.; Opatz, T. Secondary brown carbon formation via the dicarbonyl imine pathway: Nitrogen heterocycle formation and synergistic effects. Phys. Chem. Chem. Phys. 2016, 18, 18353-18364. [CrossRef]

68. Bernstein, J.A. Overview of diisocyanate occupational asthma. Toxicology 1996, 111, 181-189. [CrossRef]

69. Redlich, C.A.; Karol, M.H. Diisocyanate asthma: Clinical aspects and immunopathogenesis. Int. Immunopharmacol. 2002, 2, 213-224. [CrossRef]

70. Hu, Y.; Li, C.-Y.; Wang, X.-M.; Zhu, H.-L. ChemInform Abstract: 1,3,4-Thiadiazole. Synthesis, reactions and applications in medicinal, agricultural and materials chemistry. Chem. Rev. 2014, 114, 5572-5610. [CrossRef]

(C) 2019 by the authors. Licensee MDPI, Basel, Switzerland. This article is an open access article distributed under the terms and conditions of the Creative Commons Attribution (CC BY) license (http://creativecommons.org/licenses/by/4.0/). 